\title{
An Analysis of Subjectivation Processes Mediated by New Digital Technologies
}

\author{
https://doi.org/10.3991/ijet.v15i24.19315 \\ Douglas Rossi Ramos \\ São Paulo State University, São Paulo, Brazil \\ dddr2@hotmail.com
}

\begin{abstract}
The new advent of digital, recurrently called by some authors as Web 2.0, Web 3.0 and Internet of Things, less than a mere technological change, consists of a new communicational paradigm. Mobile technologies, such as smartphones, have gained increasing prominence as means and tools of communication and mediators of interaction, in such a context. In this work, we intend to discuss mobile technology, especially smartphones, as mediators of social practices and modes of subjectivity today. For the analysis, the notion of remediation by the Spanish sociologist Amparo Lasén was used, which, in a general scope, concerns the reconfiguration of mediations on the self-practices due to the adoption of new technologies as mediators of social practices. Among the results, the subjectivity process mediated by mobile technologies can be divided into two axes of analysis: One referring to identification, knowledge sharing and self-awareness, and the other to control and dependence. The use of this type of digital mobile technology, such as smartphones, does not consist merely of just 'one more' media technology, which would minimally influence the processes of constituting subjectivities, on the contrary, it relates to an effective device for intermediating self and social-practices.
\end{abstract}

Keywords—Digital, Mobiles, Remediation, Self-Practices, Smartphones

\section{$1 \quad$ Introduction}

Nowadays, the use of digital technologies in the most different areas and contexts is becoming increasingly intertwined with social life. From the mid-90s to the $2000 \mathrm{~s}$, we would have the evolution of what many authors would call Web 1.0, characterized by publications of static content such as, for example, web pages (news sites, companies) developed by companies and accessed unilaterally by internet user. Around 1999 and 2004, Web 2.0 would start to be formed, which would be based on collaborative projects, such as blogs ('digital diaries' or pages for the publication of personal content) and wikis (consisting of a set of pages interconnected and that can be visited and edited by any internet user, such as the virtual encyclopedia Wikipedia). While on Web 1.0 the vast majority of users act as consumers of content, on Web 2.0 any participant can also be a creator (Cormode \& Krishnamurthy, 2008). 
According to O'Reilly (2005), some of the main characteristics of Web 2.0 consist of the participation of users as co-developers of the services, and also the configuration of software that does not have its use limited to a single device (can be 'run' 'and accessed on smartphone, computer, tablet, among others). Web 3.0 consists of the semantic web or intelligent web, whose main characteristic is the use of machines to perform more efficiently activities that previously depended on manual labour (for example, the use of algorithms to perform activities that, before, depended on manual labour - marketing automation). The internet of things consists of the digital interconnection of everyday objects with the internet, in order to communicate with each other, acting as communicating beings or entities (Hendler, 2009).

The emergence and convergence of two growing industries, the Internet and mobile communications, has provided the creation of an emerging market for mobile commerce (m-commerce), or wireless commerce and mobile e-commerce. There are several definitions in the academic and practitioner literatures regarding this phenomenon (Techatassanasoontorn \& Kauffman, 2005).

Tarasewich et al. (2002), for example, defines m-commerce as any activity related to a potential commercial transaction conducted through communication networks that interface with wireless devices. Techatassanasoontorn \& Kauffman (2005) think that this definition is overly broad and may, therefore, include the use of mobile phones for voice communication.

The extent of the diffusion of m-commerce activities in a country is related to the number of mobile phones, being that there are different patterns of diffusion in different countries. In particular, countries such as Finland, Japan, Korea and Hong Kong, have seen a rapid increase in mobile phone incorporation, while others, such as India and the United States, have seen a more gradual increase in mobile phone penetration (Foong, 2001).

Similarly, pan-European regulatory policy in support of a uniform Global System for Mobile (GSM) communications standard has been essential in the growth and penetration of mobile phones in several European countries. Communication technologies are subject to consumption network externalities, such as, external factors (government policies, mass media communications, the level of competition and the number of standards) and internal factors (word-of-mouth communications) (Foong, 2001).

Digital mobile technology and its expansion thus constitutes objects and devices that mediate social practices and the experience that the individual makes of himself. In this paper, we intend to discuss mobile technology, especially smartphones, as a mediator of social practices and modes of subjectivity today. To this end, a discussion was held based on the notion of remediation, by the Spanish sociologist Amparo Lasén, which, in a general context, concerns the reconfiguration of mediations in selfpractices due to the adoption of new technologies as mediators of social practices. We will start from two axes of analysis to discuss the subjectivation process mediated by digital mobile technologies: one related to identification, knowledge sharing and selfawareness, and the other to control and dependence. 


\subsection{Remediation: Concept of analysis}

According to Lasén (2014), new communication technologies are also, as Foucault would call them, 'technologies of the self' since they participate in conflicts and complementarities in the construction of themselves. In this sense, if subjectivity can be considered an active self-training process, never completely individual or collective, through actions and operations on our bodies, thoughts and behaviours, such information technologies would be directly involved in the mediation of these movements, during their exchanges and communication practices between individuals, groups and institutions.

Still according to Lasén (2014), in the specific case of mobile technologies (cell phones, smartphones, among others), this movement would act in two axes: one referring to identification, sharing knowledge and self-awareness, and the other to control and dependence. About the first axis, the emergence and performance of these elements in the midst of mobile technologies depend, to a large extent, on the power of enrolment (the storage capacity and performance of enrolments in software and hardware). The elements of the second axis, on the other hand, would be related to the demand for recognition, triggered and driven by these services and technological mechanisms, which would be understood, in such perspective, as modalities of subjection and dependence.

It was possible to observe that the use of this type of digital mobile technology, such as smartphones, does not consist of merely 'just another' media technology, which would minimally influence the processes of constituting subjectivities. On the contrary, just as subjectivity can be problematized in terms of self-practices or technologies of the self, as explained in Foucault (1978), there are currently unfolding of these agencies from concrete intermediation devices, also materialized in the midst of appropriations of said technological artefacts. Mobile communication, as a smartphone, contributes to the affective economy and the management of emotions (Lasén, 2011).

To this new aspect, which refers to the approximation and mediation of practices, techniques and relationships of the self through these new mobile technologies, Lasén (2014) would attribute the name 'remediation'. In a general context, remediation concerns the reconfiguration of mediations in the self-practices and in the ways of acting in the world. Remediation consists of updating practices that will be translated into other means and terms, that is, the relationships that would previously be mediated in such and which ways, through the use of certain technological artefacts, would be (re) mediated in other ways, from the emergence of new mediation technologies (there is a re-mediation of these practices, from the advent of new 'mediators': Technological instruments of mediation) (Lasén, 2011).

Therefore, a remediation would be related to media environments that tend to allow some means to be translated by other means and contents, in order to force a changing repositioning in the individual's actions. These are actioning whose characteristics are composed of multiplication, extension, hyper-mediation and immediacy (Lasén \& Casado, 2012). 
As an example, it can be said that 'calls' / 'calls' via telephones, or even sending SMS (text message), would come to remedy love rituals previously incarnated in landline calls and love letters. Such remediation would highlight new dimensions between dualisms, such as proximity / distance and absence / presence.

\subsection{Remediation as discontinuity}

Currently, the smartphone and instant messaging services such as WhatsApp remedy rituals of intimacy and connectivity previously embodied in landlines and SMS, constituting a repositioning in the ways of connections and establishments of contact.

According to Lasén (2004), mediation by mobile technologies transforms and reconfigures bonds, habits, forms of power, resources and ways of doing and perceiving. This points to the discontinuity of the practices that impose and configure these new mediations.

According to the author, amidst the remedied practices, it is sometimes very difficult or almost impossible for individuals to remember how they organized their lives before their existence of these artefacts (for example, before cell phones or smartphones existed, how did they communicate and organize themselves?).

For Lásen (2014), an example of these discontinuity relationships is in the contrasts of the recurrent use of these devices in current contexts and situations, in which their use conflicts with existing norms of etiquette or socially expected behaviours (these cases reflect elements of the 'new 'in coexistence and tension with elements of the' old ', and not in a relationship of exclusion or absence).

In this sense, less than a simple 'evolutionary line' of these appropriations and behaviours, whose ascendancy would be proportional to the origins of new technological apparatuses, the 'mediated' practices tend to be updated, reopened and reconfigured in a relation immanent to the conjuncture or particular contexts. It is a hybrid movement that combines the organic with the inorganic (Di Felice, 2013).

The recent case that occurred in 2015 in which WhatsApp was blocked in Brazil, during 12 hours, at the request of a judge of the 1st criminal court in São Bernardo do Campo, in retaliation for the fact that the responsible company did not cooperate with the supply of user data for a police investigation, illustrates these notes made by Lasén (2014).

The initial punishment would be blocking for 48 hours; however, this prohibition was lifted according to the intervention of another judge, in order to last only about 12 hours. Same so, so promptly, many 'memes' began to emerge on digital social networks, alluding to the unusual and sudden blockade.

The following figures, for example, express supposed reactions of 'despair' due to the circulation of the news of the blockade for 48 hours, whose scenarios represent a person passed out in the bathroom after receiving the news; another astonished, feeling sick and receiving saline: 


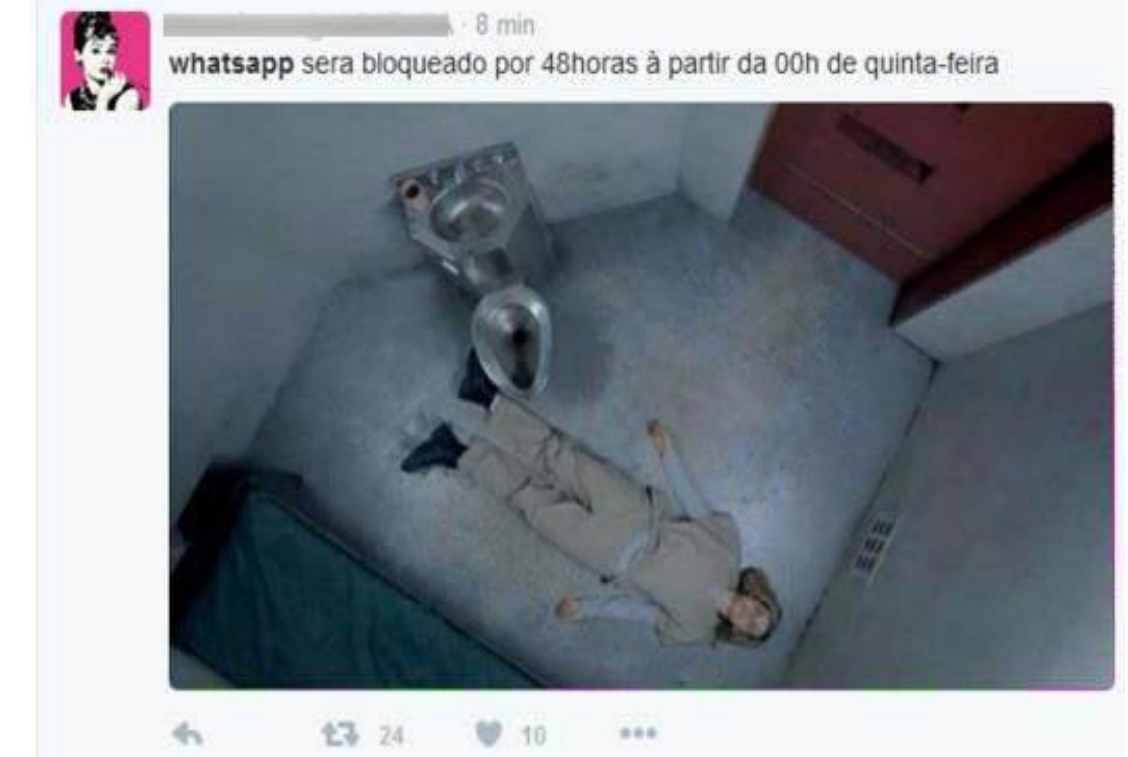

*Source: (Canaltech)

Fig. 1. Fainting: (translation of the caption: WhatsApp will be blocked for 48 hours from 00 hours on Thursday)

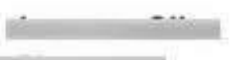

20. 2 seguir

\section{WhatsApp bloqueado por 48 h e não deve funcionar no Wi-Fi.}

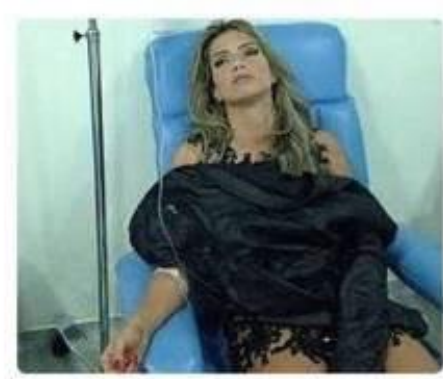

Source: (blog conecte)

Fig. 2. Feeling sick: (translation of the caption: "WhatsApp blocked for 48 hours and should not work on Wi-Fi")

The word "Meme" consists of a term coined by the British writer Richard Dawkins, in his book 'The Selfish Gene' (The Selfish Gene, released in 1976). Dawkis (2007) 
derived the ancient Greek term 'mimema', which designated 'what is imitated', for 'memetics', so that a 'meme' would be a unit of information that multiplies from brain to brain or between locations in that information can be stored, such as books, computers and the internet. On the internet, the expression 'meme' would be used to characterize ideas, concepts or even any information that would spread quickly through the web. A 'meme' can be a phrase, video, link, sound, and, recurrently, figures and illustrations assembled with real characters or imaginary in order to achieve different goals, such as fun, criticism, sarcasm, among others.

These figures (memes) show, on the one hand, the 'dependency' that the use of the application would have provided in their practices and, on the other, the eminent difficulty in rearticulating them or in rescuing other ways and strategies of 'doing what they have always done before the existence of the digital application (however using other means and techniques) (Lasén, 2010a).

It should also be noted that the solution found by most WhatsApp users was not to spend those 12 hours of blocking without using the service, or even to replace it with other techniques and strategies, but, on the contrary, it was resorting to the use of VPN (Virtual Private Network) to 'scam' through the connection mediated in public networks (Ramos, 2016).

In the same trend, there were massive downloads registered on application sites competing with WhatsApp, which were downloaded in order to continue using this same way of exchanging relationships.

Still following examples of posts regarding the judicial block, in the next figures it is possible to observe 'memes' that refer to methods used:

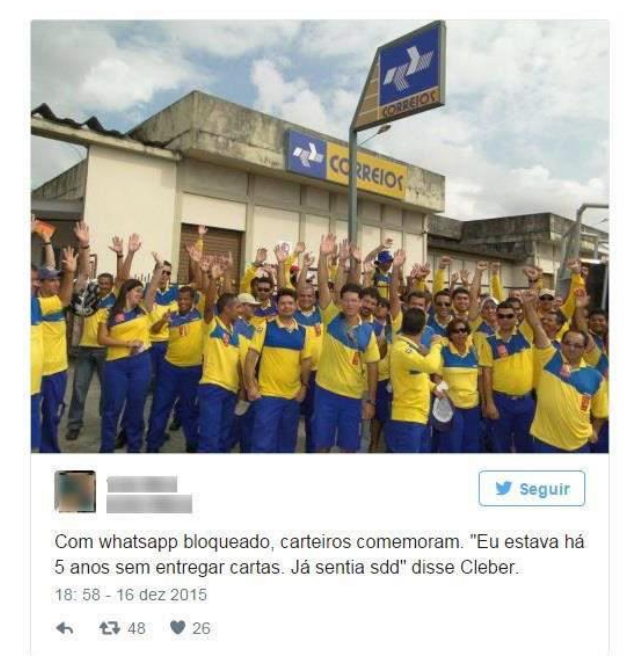

Source: (Exame tecnologia)

Fig. 3. Post offices celebrate: (translation of the caption: "With WhatsApp blocked, postmen celebrate- I had not delivered letters for years. I missed it already, said Cleber".) 
The previous figures present 'montages' that 'irony' and allude to the use of personal paper letters, repeatedly sent by post (postman's), which have already been one of the main methods for exchanging messages and correspondence. Below, memes refer to repositioning the dimension of intimacy, for example, regarding contact with people close or distant, due to their characteristics of ubiquity.

In the following figures, there are 'memes' that satirize the WhatsApp block by indicating that many people will be forced to relate face to face, offline:

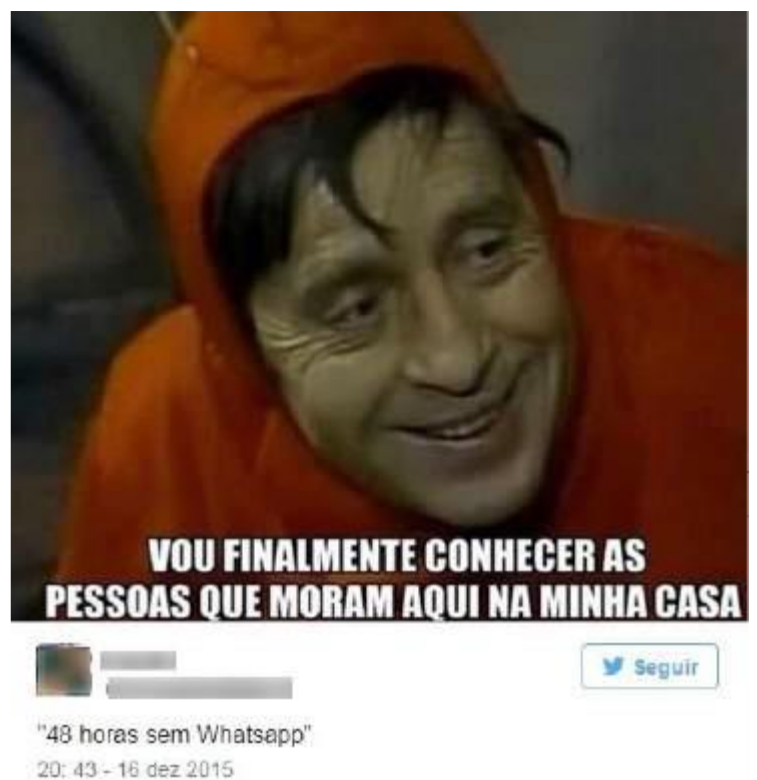

Source: (Exame tecnologia)

Fig. 4. Meeting the people at home: (translation of the caption: "I'm finally going to meet the people who live here at my house")

There are still memes that present satires to contrasting situations concerning the use application in contexts with specific rules and functions for social behaviour, such as in traffic and work environments.

In the following figures, reference is made to the constant use of WhatsApp in diverse contexts, which would even hinder 'the country's economic growth' and 'national public security': 


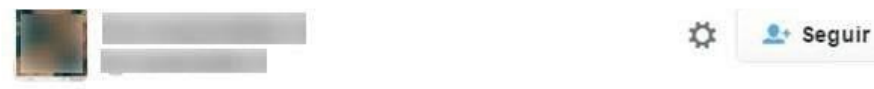

\section{Com bloqueio do Whatsapp acredita-se que pelo menos 20.000 mortes por atropelamento, tropeções e mal-entendidos serão evitadas...}

Source: G1 - technology and games

Fig. 5. WhatsApp in traffic: (translation of the caption: "With the blocking of WhatsApp, it is believed that at least 20,000 deaths from pedestrian accidents, stumbles and misunderstandings will be avoided")

The first group of 'memes' (related to the situation of despair through the blocking of WhatsApp) express a feeling of anguish and irritation through the prolonged 'abstinence' from the internet. These feelings express not only the discomfort and concern about having to use it for work purposes (such as doing work and answering professional e-mails), but, above all, the fact that today, 'being connected' to the digital network is also 'being connected' to the social world. (Ramos, 2011).

This is best evidenced by the second set of 'memes' (those that refer to the oldest methods and means of written communication). What is at issue in the context of the 'WhatsApp blockade' is not to remember or rescue old ways and tools to replace the present technologies, but to re-enrol in this core of social connections and interactions of extreme relevance and representativeness in the current context. It is not just about giving up tools and means in search of others. The social being is the connected being, and in the current context, the maximum representation of this connection is presented in digital, since, whether at work, at school, with friends or family, conversations, in one way or another, they refer to facts, subjects and elements concerning the internet and digital (on a symbolic level), even when they are not effectively connected via hardware (digital artefacts) (Lasén, 2010b).

About the third set of 'memes' (which refer to the intimate relationship with people geographically close and distant), there is a repositioning of the dimension of intimacy and the establishments of contacts in digital. In this sense, it is common to plan and manage 'channels' and connection groups, according to interests, affinities, and, in line with the daily activities.

In this sense, there are times when interlocutors use the application to talk to people close to them, such as those who would be in neighbouring environments within a university, or distant, for example, with geographically distant interlocutors. This segmentation practice in types of groups (groups of friends to go out, friends childhood, college, family, among others) also requires, in some sense, a redistribution of forms of self-presentation and self-reveal to be guided, in each context of relationships, according to objectives (group intention) and looks (interlocutors in each channel), in addition to providing different effects in the constitution of an economy of pleasure (Ramos, 2011). 
Finally, the fourth set of 'memes' (which refer to the continued use of application and that would present conflicts in contexts of practices, such as, at work and in traffic) make explicit how these digital technologies, due to the mobility character of the smartphone, would be incorporated in different contexts (including in particularly regulated places, such as work and traffic). In this regard, it is possible to observe that in a WhatsApp group, members tend to access the application, frequently, in the most different scenarios and environments, such as at university, work and hometowns.

\section{Conclusion}

The mobility of the smartphone, the low cost and the dynamism in sending different types of messages (video, text, audio), allow these contrasts and subversions to functions defined in specific territories. Such interpositions of the uses of the application in different environments, would constitute a heterotopy of deviation, since, if the social rule would be leisure (in appropriate and limited times and spaces), the use of the digital artefact in a daily work and study, constitutes a 'forged space' for leisure.

There is yet another development to be observed in the issue of 'remedies'. In According to Lasén (2014), the term 'remediar' finds a parallel with 'remedy', which comes, etymologically, from the term 'pharmacia' (from the Latin), and which is a derivative of 'pharmakon' (from the Greek), whose meaning it would be 'poison, drug and enchantment'. According to Lasén (2014), Derrida (1997), in his text 'Plato's pharmacy', when discussing the opposition between speech and writing, resorts to the idea of pharmakon in its dubious sense and which can, therefore, be translated as 'medicine and poison'.

These 'remedy' attributions (as medicine and poison), as expounded by author, find expression in the idea that, on the one hand, digital social networks are for 'socialization', but, on the other hand, this socialization is not necessarily desirable also in offline spaces (face to face). Remediation can also present a dubious feeling that there is satisfaction in talking and interacting via digital social networks, however, there is a feeling that the experiences of interrelationships could 'be better', or even that 'there are better modalities of relationships' than those expressed there.

Finally, the experiences and reports presented emphasize new appropriations and production of meanings concerning current modalities of 'remedied interrelationships' (using a digital technological artefact). These practices have a discontinuous character and comprise territories, surroundings, scenarios and spaces in a hybrid between online and offline, which are not isolated or excluded, but are corresponding.

Remediations, in addition to the mere acquisition of a new media artefact or technological, encompass practices that rescue and revalidate past performances, speeches, situations and interactions, so that we continue to do what we knew how to do (call, chat, date, meet) but with new participants (smartphones, WhatsApp), in a reconfiguration of different times, places and meanings, based on similar relationships and interactions. 


\section{Acknowledgement}

I thank "Fapesp - Fundação de Amparo à Pesquisa do Estado de São Paulo" for funding this research.

\section{$4 \quad$ References}

[1] Cormode, G., \& Krishnamurthy, B. (2008). Key differences between Web 1.0 and Web 2.0. First Monday, 13(6). https://doi.org/10.5210/fm.v13i6.2125

[2] Dawkins, R. 1941-. (1989). The selfish gene. Oxford; New York: Oxford University Press.

[3] Di Felice (2013). Being networks: the digital formism of net-activist movements. Matrizes: USP. https://doi.org/10.11606/issn.1982-8160.v7i2p49-71

[4] Foong, K. Y. (2001) Wireless services: Japan. Gartner Research Note, DPRO-92232.

[5] Foucault, M. 1926-1984 (1978). The history of sexuality. New York: Pantheon Books

[6] Hendler, J. (2009). Web 3.0 Emerging, in Computer, vol. 42, no. 1, pp. 111-113, http: //doi.org/10.1109/MC.2009.30 .

[7] Lasén, A. (2004). Affective Technologies: emotions and mobile phones. Surrey: The Digital World Research Centre [Online]. Available: www.surrey.ac.uk/dwrc/Publications/All Pubs.pdf

[8] Lasén, A. (2011) Mobiles are not that personal: the unexpected consequences of the accountability, accessibility and transparency afforded by mobile telephony. New Brunswick, NJ, pp. 83-105.

[9] Lasén, A. (2010a) Mobile culture and subjectivities: an example of the shared agency between people and technology, in: Interacting with Broadband Society, eds Leopoldina Fortunati, Jane Vincent, Julian Gebhardt, Andraz Petrovcic \& Olga Vershinskaya, Peter Lang, Frankfurt am Main, pp. 109-123. https://doi.org/10.1177/17427665110070020703

[10] Lasén, A. (2010b) Mobile media and affectivity: some thoughts about the notion of affective bandwidth, in: Mobile Media and the Change of Everyday Life, eds Joachim R. Hoflich, Georg F. Kircher, Christine Linke \& Isabel Schlote, Peter Lang, Frankfurt am Main, pp. 131-153. https://doi.org/10.3726/978-3-653-01460-0/16

[11] Lasén, A. (2014). Remediaciones móviles de subjetividades y sujeciones en relaciones de pareja. Madrid: CIS.

[12] Lasén, A. y Casado, E. (2012). Mobile Telephony and the Remediation of CoupleIntimacy. Feminist Media Studies, 12(4), pp. 550-559. https://doi.org/10.1080/14680777.2012.74 $\underline{1871}$

[13] O'reilly, T. (September 2005). What is web. 2.0. Design Patterns and Business Models for the Next Generation of Software. O'Reilly Media [Online]. Available: http://www.oreilly net.com/pub/a/oreilly/tim/news/2005/09/30/what-is-web-20.html

[14] Tarasewich, P, Nickerson, R. C. Warkentin, M. (2002). Mobile e-commerce, Communications of the Association for Information Systems. Article 3. 41-64.

[15] Techatassanasoontorn, A.A., Kauffman, Robert J. (2005). International Diffusion of Digital Mobile Technology: A Coupled-Hazard State-Based Approach. Information Technology and Management 6, 253-292. https://doi.org/10.1007/s10799-005-5882-3

[16] Ramos, D. (2016). The neo-narcissism in the society of control: resistances and production of subjectivity. Doctoral thesis. Institute of Psychology of the University of São Paulo. 


\section{$5 \quad$ Author}

Douglas Rossi Ramos holds a PhD in psychology from the University of São Paulo. Currently undergoing post-doctoral exchanges with the communication department of Universidade Nova de Lisboa, where he studies the question of memory and perception in the new conjuncture of digital.

Article submitted 2020-10-23. Resubmitted 2020-11-26. Final acceptance 2020-11-26. Final version published as submitted by the authors. 